\title{
A trophic model of the benthopelagic fauna distributed in the Santa Maria di Leuca cold-water coral province (Mediterranean Sea)
}

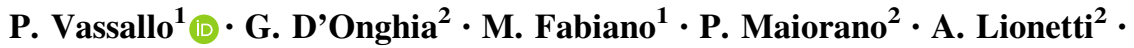 \\ C. Paoli ${ }^{1}$ - L. Sion ${ }^{2} \cdot$ R. Carlucci ${ }^{2}$ \\ ${ }^{1}$ Dipartimento di Scienze della Terra, dell'Ambiente e della Vita, Università di Genova, Corso Europa 26, 16132 Genoa, Italy \\ 2 Dipartimento di Biologia, Università di Bari Aldo Moro, Bari, Italy
}

Received: 8 September 2016/Revised: 13 October 2016/Accepted: 27 November 2016/Published online: 9 December 2016 (C) Joint Center on Global Change and Earth System Science of the University of Maryland and Beijing Normal University and Springer-Verlag Berlin Heidelberg 2016

\begin{abstract}
The benthopelagic fauna distributed in and around the Santa Maria di Leuca (SML) cold-water coral (CWC) province (Northern Ionian Sea-Central Mediterranean Sea) was analyzed through the development of a mass-balanced ecosystem model. A total of nine balanced simulations were provided taking into account the biomass data collected during several experimental bottom trawl surveys carried out from 2005 to 2010 in a depth range between 101 and $541 \mathrm{~m}$. A total of 100 species were included in the analysis corresponding to 15 cephalopods, 25 crustaceans, 7 chondrichthyes and 54 osteichthyes. Simulations were developed maintaining the species-level detail. The total system throughput estimated in the SML CWC province trophic web resulted mainly due to consumption and about $80 \%$ of it was maintained by species with trophic level between 2 and 4. Results highlighted important features in terms of the structure and functioning of the system, such as the high level of activity maintained by intermediate trophic levels and the important role of top-down control in the faunal assemblage due to both vertebrate and invertebrate species.
\end{abstract}

Keywords Ecopath · Mass-balance model · Keystoneness - Total mixed trophic impact

Electronic supplementary material The online version of this article (doi:10.1007/s40974-016-0047-2) contains supplementary material, which is available to authorized users.

P. Vassallo

paolo.vassallo@unige.it

\section{Introduction}

The Santa Maria di Leuca (SML) cold-water coral (CWC) province in the Northern Ionian Sea is the widest and deepest known deep-sea coral community in the Mediterranean (Freiwald et al. 2009; Savini et al. 2014) and also the most investigated using a multidisciplinary approach (Corselli 2010). It is well reckoned as a biodiversity hot spot of the Mediterranean Sea bathyal grounds (Tursi et al. 2004; Mastrototaro et al. 2010; D'Onghia et al. 2011, 2012). The diversity of the SML CWC habitat is considered to be due to the local bathymetric features (Savini et al. 2014) and fostered by the trophic system and hydrographic factors acting in the Northern Ionian Sea (Budillon et al. 2010). In addition, the SML CWC province could be considered an almost un-disturbed area because trawling does not occur being formally illegal (GFCMRAC/SPA 2007). However, local fishermen aiming the catch of large specimens generally adopt the "fishing the line" strategy trying to avoid gear damage and losses (Indennidate et al. 2010; D’Onghia et al. 2016).

As a matter of fact, the Mediterranean region has been inhabited for millennia and ecosystems were altered in many ways (Bianchi and Morri 2000; Viettia et al. 2010). In particular, fishing activities were proposed as the first major human disturbance in coastal areas (Jackson et al. 2001). This makes the SML CWC province an ad-hoc area to study a less exploited demersal community in the Mediterranean basin. Recently, the SML CWC province was mostly investigated during the Apulian PLAteau Bank Ecosystem Study (APLABES) project (Corselli 2010), funded for the FIRB programs by the Italian Ministry of Universities and Research (MIUR) and during the 
CoralFISH project funded by EU 7FP (www. eu-fp7-coralfish.net) (Capezzuto et al. 2012; D’Onghia et al. 2012).

Studies on the demersal resources were carried out since 1985 in the North-western Ionian Sea as part of national and international bottom trawl surveys (Relini et al. 2000; Bertrand et al. 2000, 2002) providing a large amount of information on benthic fauna and benthopelagic fish, crustaceans and cephalopods. In addition, specific studies were carried out inside or outside the SML coral province (e.g., Matarrese et al. 1996; D'Onghia et al. 1998, 2003, 2010; Capezzuto et al. 2010, 2012; Maiorano et al. 2010). However, a comprehensive description of the structure and functioning of this ecosystem is still lacking.

In the present study, we applied a steady-state massbalanced model for the representation of the food web connecting the benthopelagic mobile fauna (cephalopods, crustaceans and fishes) distributed in and around the Santa Maria di Leuca cold-water coral province. The main objectives are those of evaluating the structure and functioning of the investigated fauna assemblage in terms of trophic flows, analyzing the ecological role of different species and investigating the consequences of the protection from fishing offered by corals.

\section{Materials and methods}

\subsection{Study area and surveys}

The cold-water coral province is located about $25-45 \mathrm{~km}$ far the coast of Cape Santa Maria di Leuca (Fig. 1). This coral province extends over a broad area between 300 and $1100 \mathrm{~m}$ in depth and is formed by clustered and isolated coral mounds $50-300 \mathrm{~m}$ in diameter and up to $25 \mathrm{~m}$ in height (Taviani et al. 2005; Savini and Corselli 2010; Savini et al. 2014). Coral frameworks are mainly built by the colonial scleractinians Madrepora oculata and Lophelia pertusa.

Data were collected during bottom trawl nets (GRUND 2005, 2006, 2008; MEDITS 2005-2010) over muddy bottoms as close as possible to this coral province and were arranged in a set of 9 simulations as reported in Table 1 .

A total of 100 species were included in the analysis to describe the ecological model of the SML demersal (benthopelagic fauna) assemblages distributed between 101 and $541 \mathrm{~m}$ of depth. In particular, the list of 15 cephalopods, 25 crustaceans, 7 chondrichthyes and 54 osteichthyes was provided as supplementary material (Table S1).

\subsection{Modeling approach}

The characterization of an ecosystem in terms of structure and functioning is based on the knowledge of the quantity and intensity of flows acting within the system (Vassallo et al. 2006, 2013). Flows estimation is possible through the development and calibration of a trophic web simulation here performed with Ecopath 5.0 software (Christensen et al. 2005). The software uses a set of linear equations in order to balance the flows (in and out) of each component or functional group (in this study the species) (Christensen 2003). For a basic parameterization, the simulation's routine uses a system of linear equations, which can be expressed for an arbitrary time period by:

$B\left(\frac{P}{B}\right)_{i}=\sum B_{j}\left(\frac{Q}{B}\right)_{j} \mathrm{DC}_{i j}+E_{i}+\mathrm{BA}_{j}+B_{i}\left(\frac{P}{B}\right)_{i}\left(1-\mathrm{EE}_{i}\right)$

Consumption $=$ Production + Unassimilated food

$$
+ \text { Respiration }
$$

In Eq. (1), $B$ is the biomass, $P / B$ indicates the production of $(i)$ per unit of biomass and it is equivalent to total mortality under steady-state conditions (Allen 1971), $Q /$ $B$ is the consumption of $(i)$ per unit of biomass, $\mathrm{DC}_{\mathrm{ij}}$ indicates the proportion of prey $(i)$ that is in the diet of predator $(j)$ in terms of weight units, $E$ is the net migration of the system, BA is the biomass accumulation in the ecosystem and EE is the ecotrophic efficiency of the group within the system, or the proportion of the production of (i) that is exported out of the ecosystem or consumed by predators within it. Under the assumption of mass balance, EE cannot be $>1$. Equation (2) ensures the energy balance of each group in the system.

Biomass data (wet weight) were collected during experimental surveys carried out in the area, while $P / B$ and $Q / B$ ratios were obtained from the relevant literature (see supplementary material-Table S1). The diet matrix is a key factor for a realistic simulation, but the quantitative assessment of prey/predation relationships is often difficult (Paoli et al. 2016). In this study, the diet matrix was obtained according to MATBLD method (Ulanowicz and Scharler 2008). The method is based on the recognition of predation path by means of an adjacency matrix, while the diet fluxes are assigned according to the joint proportion of predator demand and prey availability. Adjacency matrix (see supplementary on-line material) was compiled through the analysis of relevant literature (see supplementary material-Table S1). The MATBLD routine does not necessarily balance the network, and the software routine gives an error message if the simulation output is not realistic. In particular, it checks if the ecotrophic efficiency is $<1.0$ for all compartments. If inconsistencies $(\mathrm{EE} \geq 1)$ were detected, the system was brought into balance by some automated schemes, such as linear donor control (Allesina and Bondavalli 2003). Even though modifications 
Fig. 1 Map of the Santa Maria di Leuca cold-water coral province within the Mediterranean Sea and bathymetric framework within the southern Apulia margin in the North-western Ionian Sea
Table 1 Simulation networks with indication of survey, data, number of simulations, sampling gear, and depth range

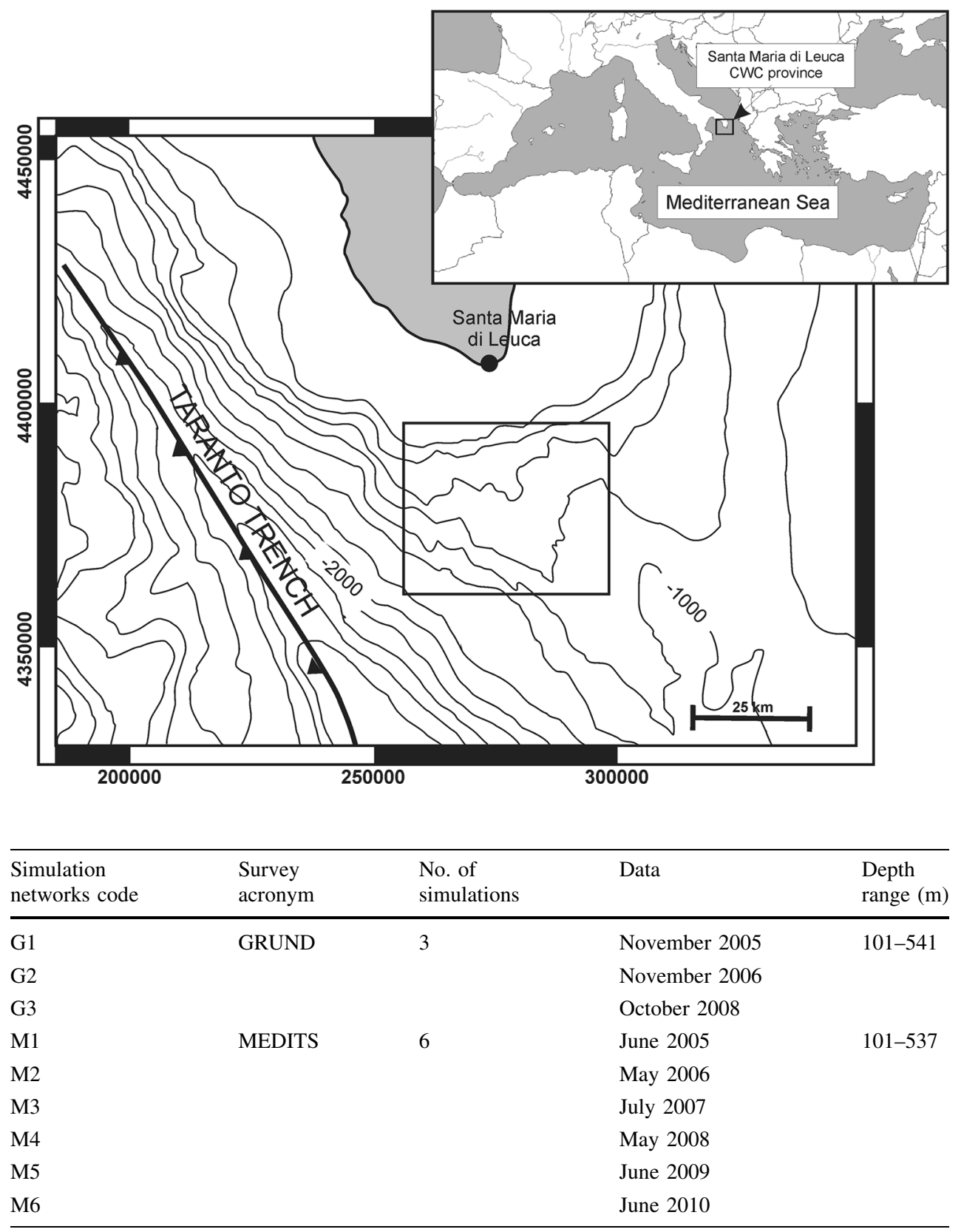

in the diet matrix were necessary, the number (and obviously the position) of fluxes remained unchanged.

It has been demonstrated that networks balanced using MATBLD do not differ from networks developed with different methods (i.e., bibliographic data) to any statistically significant degree (Ulanowicz and Scharler 2008).

Steady state was assumed for the Ecopath models parameterization, with BA and E set to zero. For the species that are known performing in and out migrations from the model area, we defined a fraction of their diets as import for the model and conversely a part of their detritus direct to the export (Tecchio et al. 2013).
Finally, a detritus group and an "other species" group were also considered representing the availability of organic matter and of small, non-sampled species on the sea bottom. Both these supplementary functional groups were quantified from previous study carried out in the eastern Atlantic and Mediterranean Sea (e.g., Sánchez and Olaso 2004; Coll et al. 2006, 2007; Tecchio et al. 2013).

\subsection{Model output}

Ecological indices were used to analyze structure and functioning of the SML benthopelagic mobile fauna based 
on trophic flows analysis, thermodynamic concepts, information theory and trophodynamic indicators (Christensen and Walters 2004).

Total trophic flows within the community in terms of consumption, production, respiration, exports and imports and flow to detritus were quantified ( $\mathrm{t}$ wet weight $\mathrm{km}^{-2}$ year $\left.{ }^{-1}\right)$. The sum of all these flows is the total system throughput (TST) that was calculated as the measure of the activity or size of the system functioning (Finn 1976).

The trophic level (TL) of each species was calculated following Odum and Heald (1975). It is conventionally ascribed a TL of 1 to primary producers and detritus, and other TLs are accordingly calculated as:

$\mathrm{TL}_{j}=1+\sum_{i=1}^{n} \mathrm{DC}_{j i} \times \mathrm{TL}_{i}$

where $j$ is the predator of prey $i, \mathrm{DC}_{j i}$ is the fraction of prey $i$ in the diet of predator $j$ and $\mathrm{TL}_{i}$ is the trophic level of prey $i$.

Network simulations allowed ascribing total system activity, calculated as the sum of consumption, respiration, excretion and natural mortality, to different species and in turn to their respective TLs aiming at the assessment of the relative importance of each trophic level in the system. The mixed trophic impact (MTI) allowed the quantification of direct and indirect trophic interactions among species (Leontief 1951; Ulanowicz and Puccia 1990). This analysis provides a quantification of the positive or negative impact that a hypothetical increase in the biomass of a species would produce on the others in the community. Moreover, the MTI was used to calculate the total mixed trophic impact (TMTI) that one species would have on the others by adding all its impacts weighted by the inverse of the biomass of the impacted groups, as proposed by Pranovi et al. (2003) and Libralato et al. (2004). This evidences the total effect that a unit change in the biomass of one species has on the predicted biomasses of the other species.

The identification of keystone species derived from the MTI analysis was also carried out according to the method proposed in Libralato et al. (2006). In particular, the keystone species are those that show relatively low biomass but have high impact on the other species in the ecosystem (Power et al. 1996). The keystoneness of each species may be represented plotting the relative overall effect $\left(\varepsilon_{i}\right)$, calculated from the MTI $\left(m_{i j}\right)$, against the keystoneness $\left(\mathrm{KS}_{i}\right)$. The overall effect $\left(\varepsilon_{i}\right)$ is described as:

$\varepsilon_{i}=\sqrt{\sum_{i=1}^{n} m_{i j}^{2}}$

where $m_{i j}$ is calculated from the MTI analysis as the product of all net impacts for all the possible pathways in the food web linking prey $i$ and predators $j$. The keystoneness $\left(\mathrm{KS}_{i}\right)$ of a species is calculated as:

$\mathrm{KS}_{i}=\log \left[\varepsilon_{i}\left(1-\frac{B_{i}}{B_{\mathrm{tot}}}\right)\right]$

where $B_{i}$ is the biomass of the species $i$ and $B_{\text {tot }}$ the total biomass of the food web. This index is high when species show both low biomass and high overall effects (Margaleff 1968; Odum 1969; Pauly and Christensen 1995) and the keystone species are those that have KS value greater than zero (Libralato et al. 2006).

\section{Results}

The main statistics describing the output of the ecological models estimated in each simulation were reported in Table 2. In addition, the network flows and information indices were reported in Table 3.

Number of species ranged from 74 to 93 and total biomass showed huge variations throughout simulations, ranging from 649.18 to $3204.06 \mathrm{t} \mathrm{km}^{-2}$. In particular, the total biomass indices resulted mainly due to the contribution of osteichthyes $(69.42 \pm 11.86 \%)$, followed by cephalopods $(11.45 \pm 6.29 \%)$, crustaceans $(10.74 \pm 4.92 \%)$ and chondrichthyes (8.39 $\pm 5.33 \%)$, as shown in Fig. 2 .

Throughout simulations, the mean trophic levels showed narrow variations with an average value of $3.94 \pm 0.15$, while the maximum trophic levels ranged from 3.73 to 4.18 (Table 2). The highest trophic levels corresponded to the presence of larger fish species such as the blackmouth catshark Galeus melastomus ( $\mathrm{TL}=3.96)$, the anglerfish Lophius piscatorius $(\mathrm{TL}=3.78)$, the hake Merluccius merluccius ( $\mathrm{TL}=3.47$ ) and the European conger Conger conger $(\mathrm{TL}=3.45)$, which were considered as opportunistic predators. Remarkable high trophic levels were also detected in cephalopods and crustaceans mainly referred to the bobtail squid Rossia macrosoma $(\mathrm{TL}=3.66)$, the broadtail shortfin squid Illex coindetii $(\mathrm{TL}=3.35)$ and the golden shrimp Plesionika martia $(\mathrm{TL}=3.35)$.

The estimated total system throughput reached $47,969.91 \mathrm{t} \mathrm{km}^{-2}$ year $^{-1}$ and was mainly dominated by the total consumption $(50 \pm 1 \%)$, followed by the total respiratory flows $(28 \pm 2 \%)$ and the total flows into the detritus $(13 \pm 2 \%)$ (Table 3).

TST resulted strongly correlated with biomass $\left(r^{2}=\right.$ $0.99 ; n=14 ; p<0.01)$ and TST/biomass ratio resulted quite stable with an average value of $13.43 \pm 2.47$.

Simulations indicated as the total system throughput estimated for the SML community was generally maintained by species with trophic levels up to 4 $(1 \leq \mathrm{TL}<2=12.54 \pm 1.50 \%$ of the TST; $2 \leq \mathrm{TL}<3=40.10 \pm 1.20 \%$ of the TST; 
Table 2 Main statistics describing the output of the ecological models estimated in each simulation

\begin{tabular}{lllcccc}
\hline Survey & $\begin{array}{l}\text { Simulation } \\
\text { networks }\end{array}$ & $\begin{array}{l}\text { No of } \\
\text { species }\end{array}$ & $\begin{array}{l}\text { Total biomass } \\
\mathrm{t} \mathrm{km}\end{array}$ & TL max & $\begin{array}{c}\text { TL mean } \\
\begin{array}{l}\text { Sum of all production } \\
\mathrm{km}^{-2} \\
\text { year }\end{array}\end{array}$ \\
\hline GRUND & G1 & 80.00 & 877.60 & 4.03 & 3.10 & 1475.00 \\
& G2 & 81.00 & 1185.11 & 3.73 & 3.14 & 2010.00 \\
& G3 & 93.00 & 676.23 & 3.73 & 3.11 & 1037.00 \\
MEDITS & M1 & 87.00 & 749.63 & 3.94 & 3.15 & 1587.00 \\
& M2 & 85.00 & 850.06 & 3.97 & 3.16 & 1541.00 \\
& M3 & 74.00 & 649.18 & 3.88 & 3.09 & 1404.00 \\
& M4 & 92.00 & 893.95 & 3.96 & 2.96 & 1481.00 \\
& M5 & 88.00 & 3204.06 & 4.18 & 3.19 & 7248.00 \\
& M6 & 92.00 & 704.39 & 4.04 & 3.07 & 1346.00 \\
& Min & 74.00 & 649.18 & 3.73 & 2.96 & 1037.00 \\
& Max & 93.00 & 3204.06 & 4.18 & 3.19 & 7248.00 \\
& Mean & 85.78 & 1087.80 & 3.94 & 3.11 & 2125.44 \\
\end{tabular}

Table 3 Ecological indicators related to the network flows

\begin{tabular}{|c|c|c|c|c|c|c|c|c|c|c|}
\hline \multirow[t]{2}{*}{ Survey } & \multirow{2}{*}{$\begin{array}{l}\text { Simulation } \\
\text { network }\end{array}$} & \multicolumn{2}{|c|}{ Total consumption } & \multicolumn{2}{|l|}{ Total exports } & \multicolumn{2}{|c|}{ Total respiratory flows } & \multicolumn{2}{|c|}{ Total flows into detritus } & \multirow{2}{*}{$\begin{array}{l}\text { TST } \\
\mathrm{t} \mathrm{km}^{-2} \text { year }^{-1}\end{array}$} \\
\hline & & $\mathrm{t} \mathrm{km}^{-2}$ year $^{-1}$ & $\%$ & $\mathrm{t} \mathrm{km}^{-2}$ year $^{-1}$ & $\%$ & $\mathrm{t} \mathrm{km}^{-2}$ year $^{-1}$ & $\%$ & $\mathrm{t} \mathrm{km}^{-2}$ year $^{-1}$ & $\%$ & \\
\hline \multirow[t]{3}{*}{ GRUND } & G1 & 5525.27 & 0.49 & 1284.49 & 0.11 & 2985.76 & 0.27 & 1461.17 & 0.13 & $11,256.70$ \\
\hline & $\mathrm{G} 2$ & 7927.28 & 0.50 & 1566.64 & 0.10 & 4415.01 & 0.28 & 1891.86 & 0.12 & $15,800.79$ \\
\hline & G3 & 4459.93 & 0.50 & 895.39 & 0.10 & 2608.05 & 0.29 & 1003.07 & 0.11 & 8966.43 \\
\hline \multirow[t]{10}{*}{ MEDITS } & M1 & 6177.24 & 0.49 & 1471.90 & 0.12 & 3470.98 & 0.27 & 1600.20 & 0.13 & $12,720.32$ \\
\hline & M2 & 5746.37 & 0.49 & 1158.36 & 0.10 & 3107.18 & 0.27 & 1632.38 & 0.14 & $11,644.28$ \\
\hline & M3 & 6205.87 & 0.51 & 940.18 & 0.08 & 3754.18 & 0.31 & 1364.04 & 0.11 & $12,264.27$ \\
\hline & M4 & 5992.11 & 0.47 & 1544.58 & 0.12 & 3333.47 & 0.26 & 2001.69 & 0.16 & $12,871.85$ \\
\hline & M5 & $24,846.74$ & 0.52 & 5076.09 & 0.11 & $12,790.86$ & 0.27 & 5256.22 & 0.11 & $47,969.91$ \\
\hline & M6 & 5121.56 & 0.49 & 1134.15 & 0.11 & 2838.48 & 0.27 & 1297.89 & 0.12 & $10,392.09$ \\
\hline & Min & 4459.93 & 0.47 & 895.39 & 0.08 & 2608.05 & 0.26 & 1003.07 & 0.11 & 8966.43 \\
\hline & Max & $24,846.74$ & 0.52 & 5076.09 & 0.12 & $12,790.86$ & 0.31 & 5256.22 & 0.16 & $47,969.91$ \\
\hline & Mean & 8000.26 & 0.50 & 1674.64 & 0.11 & 4367.11 & 0.28 & 1945.39 & 0.13 & $15,987.40$ \\
\hline & Std & 6387.60 & 0.01 & 1298.90 & 0.01 & 3204.21 & 0.02 & 1277.91 & 0.02 & $12,139.82$ \\
\hline
\end{tabular}

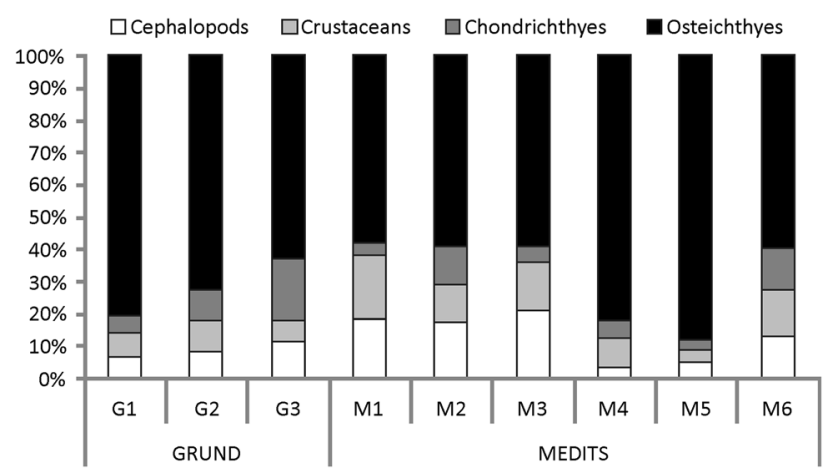

Fig. 2 Biomass contribution provided by each faunistic category
$3 \leq \mathrm{TL}<4=38.54 \pm 0.79 \%$ of the TST) (Fig. 3). The contribution of the species with $\mathrm{TL} \geq 4$ always came out lower than $9 \%$ of TST.

\subsection{Mixed trophic impact analysis and keystone index}

The total MTI analysis was carried out for each simulation in order to rank the species more influencing the biomass of the others in the analyzed trophic web. In particular, the negative and positive impacts of the species are presented for each simulation in Fig. 4. During the trawl surveys, the 


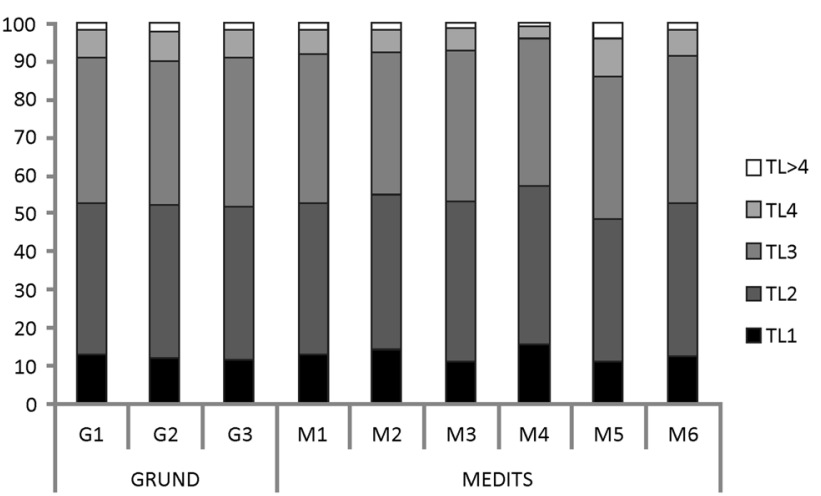

Fig. 3 Percentage distribution of the total system throughput (TST) by trophic level (TL)

shark G. melastomus and the teleosts L. budegassa and $P$. blennoides showed the highest total negative impacts together with invertebrate species such as A. foliacea, $P$. longirostris, $P$. martia and I. coindetii. Within differences by simulated networks, $P$. blennoides $M$. dypterygia, $M$. poutassou, $H$. mediterraneus, $N$. sclerorhynchus and $\mathrm{Mu}$ nida spp. ranked among the species with the highest positive impacts.

The species with highest estimated keystoneness and relative overall effect were represented in Fig. 5. For the sake of clarity, in the diagrams only the first 5 species with the highest and the lowest keystoneness, respectively, were showed. The blackmouth catshark G. melastomus, the broadtail shortfin squid $I$. coindetii and the black anglerfish L. budegassa appeared more frequently as the top keystone species.

Keystones values higher than zero (Fig. 5) are shown for each simulation.

\section{Discussion}

The characterization of the SML CWC province in terms of structure and functioning was carried out calibrating a mass-balanced model for the representation of the food web related to the benthopelagic fauna. Each simulation was based on biomass data $(B)$ directly sampled in the SML CWC province and other basic parameters (i.e., $P / B$, $Q / B, \mathrm{Un} / Q$ ) that were adopted from other similar studies performed worldwide (e.g., Neira et al. 2004; Sánchez and Olaso 2004; Zuozhi et al. 2011; Morales-Zárate et al. 2011; Bănaru et al. 2013) and in the Mediterranean Sea (Coll et al. 2006, 2007; Barausse et al. 2009; Tsagarakis, et al. 2010; Fouzai et al. 2012, Tecchio et al. 2013). In many of these studies, pelagic and demersal domains were generally integrated and simulations were developed at the level of functional group. On the contrary, in the present study, the benthopelagic mobile fauna was specifically evaluated because it was assumed to be directly influenced by the presence of corals and by the consequent reduced fishing pressure in the area (D'Onghia et al. 2010, 2011, 2012). Furthermore, for the first time to our knowledge, simulations were developed maintaining the detail at the species level. This was possible due to the accuracy of the biomass data collected during experimental surveys and the application of a specific algorithm able to compute a specific diet matrix for each simulation.

The total biomass of the SML CWC community in the Northern Ionian Sea resulted higher than the corresponding values detected in different exploited areas as the South Catalan Sea (Coll et al. 2006), the Cantabrian Sea (Sánchez and Olaso 2004), the Northern Adriatic Sea (Coll et al. 2007) and the deep open slope on the Catalan margin (Tecchio et al. 2013).

Nonetheless, the trophic levels of the species analyzed in the present study resulted in agreement with those estimated in the Aegean Sea (Mediterranean Sea) (Stergiou and Karpouzi 2002) and in a subtropical/boreal transition zone as the Cantabrian Sea (Eastern Atlantic) (Sánchez and Olaso 2004).

The total system throughput estimated in the SML trophic web related to benthopelagic fauna resulted mainly due to consumption. This result is substantially in agreement with other studies carried out in other Mediterranean basins (Coll et al. 2006, 2007). However, the throughput and the biomass/throughput estimated in the SML benthopelagic food web were higher than those estimated in the South Catalan Sea (Coll et al. 2006; Tecchio et al. 2013) and in the Northern and Central Adriatic Sea (Coll et al. 2007). In particular, the greatest part (about 80\%) of the total system throughput in the SML is maintained by species with trophic level between 2 and 4 . This result is quite different with those reported in the South Catalan Sea and in the Northern and Central Adriatic Sea (Coll et al. 2006, 2007), where a continuous decreasing trend was estimated with the increasing trophic level and highest activity detected in the first two TLs.

The SML benthopelagic trophic web seems to be much more based on the exploitation of imported material and, to lesser extent, on a detritus-based trophic structure. This is in agreement with results reported in Carlier et al. (2009) who demonstrated as the benthic food web of SML is exclusively fueled by carbon of external origin. The activity showed by the primary consumers $(1 \leq \mathrm{TL}<2)$ in this study resulted lower than the corresponding estimated in other investigated Mediterranean areas (Coll et al. 2006, 2007). These differences are likely to be ascribed to the different sources feeding the food web. In fact, shallower areas (Coll et al. 2006, 2007) are strongly linked to the pelagic domain and to the superficial primary production, while deeper areas may only be fueled by local or imported organic matter and thus forced to base on the exploitation of different sources of energy. 
Fig. 4 Rank of the species with total negative and positive impacts
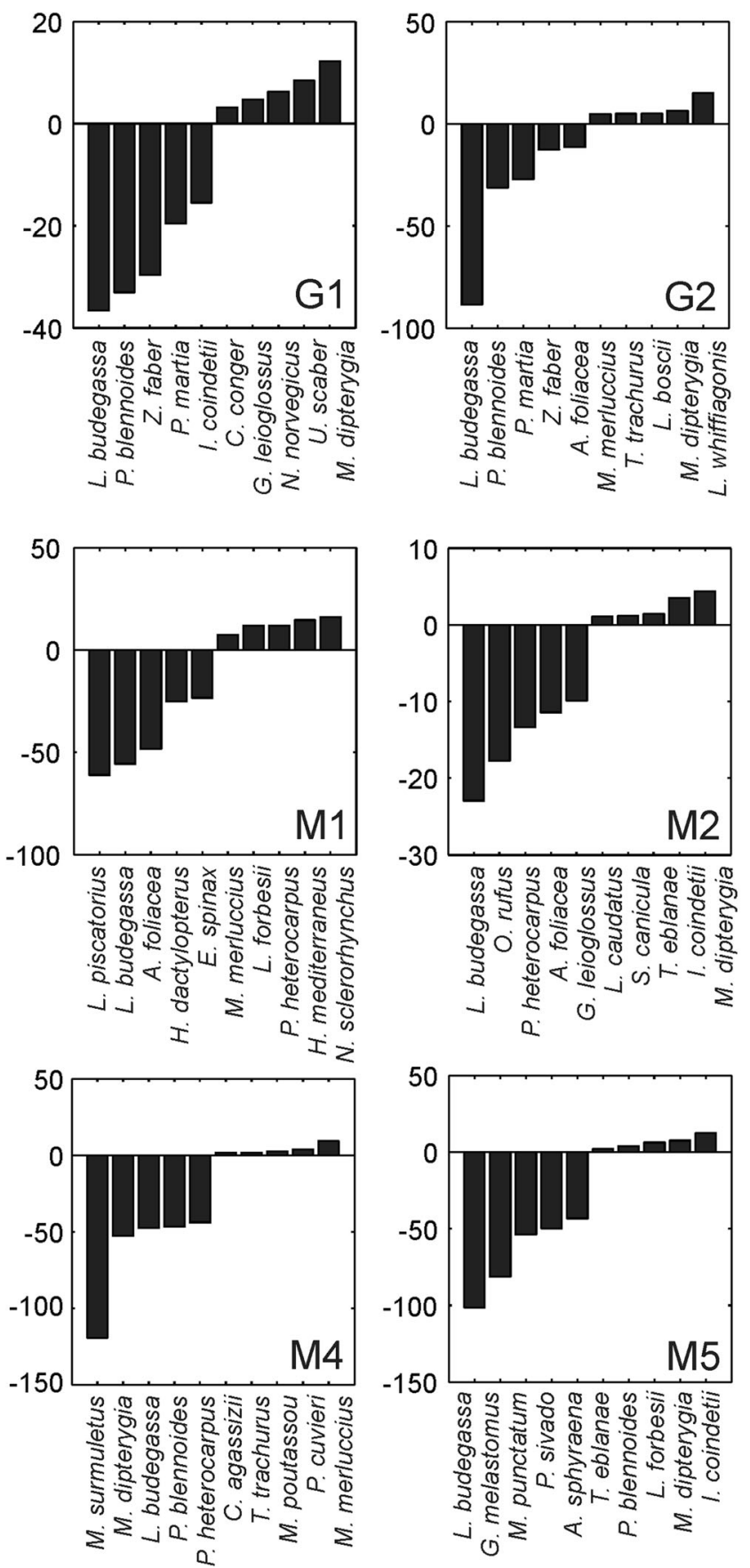
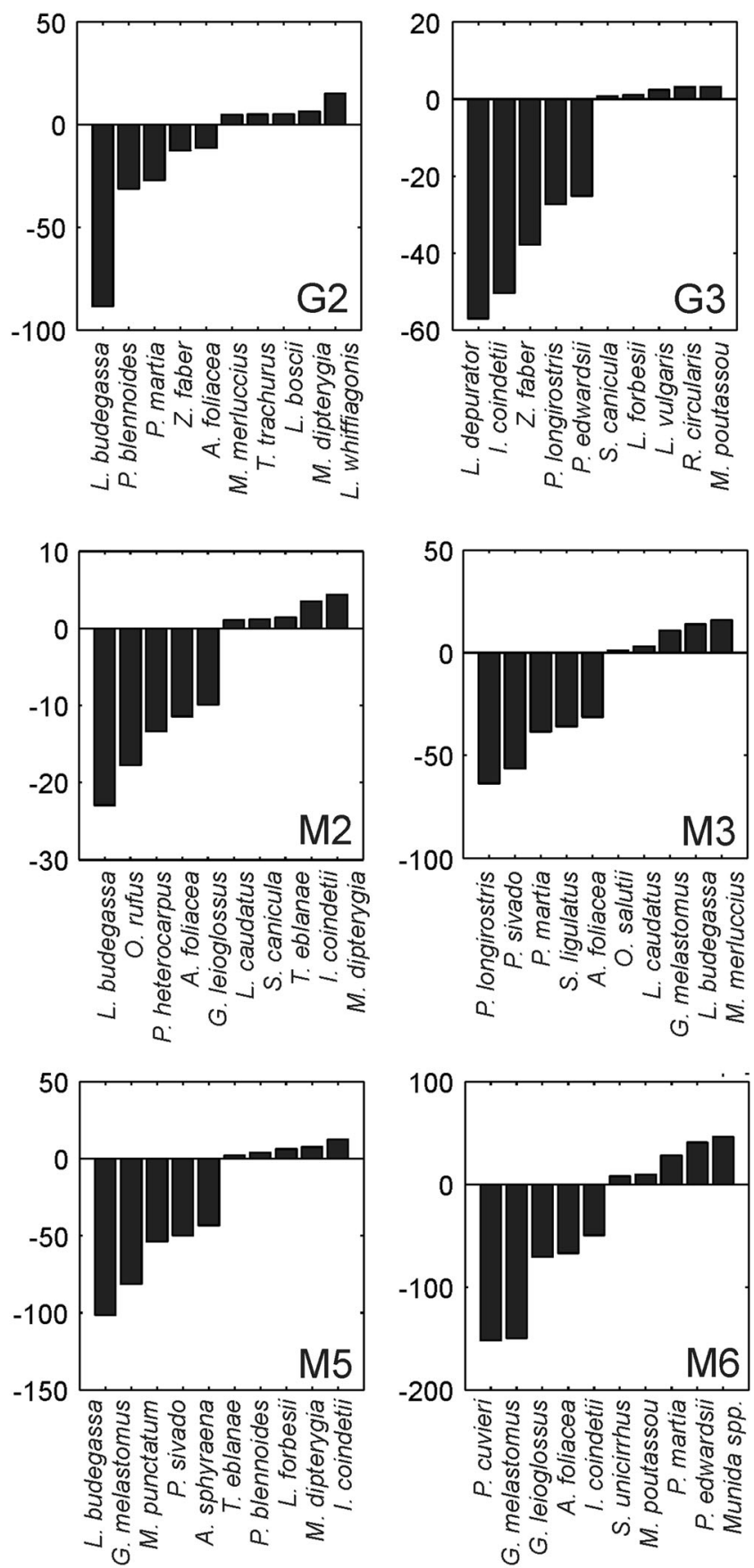

A sudden decrease in activity was recorded moving beyond the $\mathrm{TL}>4$. In fact, throughput maintained by TL $>4$ was always very low showing a certain level of unefficiency flowing available energy to higher trophic levels, indicating that the system can sustain few large top predators roaming in the area, such as the blackmouth catshark G. melastomus. This means that a significant share of production seems to be not consumed within the system. On the contrary, SML benthopelagic assemblages seem to be able to store biomass at these trophic levels maintaining high abundance of predators feeding in the area and not threatened by external pressures such as intense fishing activity that in other Mediterranean areas has been reckoned able to reduce the biomass of top predators (Bearzi et al. 2004; Coll et al. 2007).

A top-down control of high TL fishes as G. melastomus, L. budegassa, C. conger and $M$. merluccius was identified by means of their total negative impact on the other species within the system. This is mainly due to the wide range of possible preys in their diet and to their relative high abundance in the SML coral area (D'Onghia et al. 2012). The blackmouth catshark is the most abundant demersal 
Fig. 5 Overall effect for the highest and the lowest keystoneness by simulated network

\section{Relative overall effect}

\begin{tabular}{|c|c|c|c|c|c|}
\hline $\begin{array}{l}-2{ }^{6} 8 \\
8 \\
9 \\
10\end{array}$ & $\begin{array}{l}\text { 1L. budegassa } \\
\text { 21. coindetii } \\
3 \mathrm{G} \text {. melastomus } \\
\text { 4 P. martia } \\
\text { 5P. multidentata } \\
6 \mathrm{R} \text {. pallidus } \\
7 \text { P. narval } \\
\text { 8A. lacazei } \\
\text { 9 L. friesii } \\
\text { 10 L. elegans }\end{array}$ & $-\left.2\right|_{10} ^{0}$ & $\begin{array}{l}503201 \\
\text { 1L. budegassa } \\
\text { 2. G. melastomus } \\
\text { 3. I. condetii } \\
\text { 4P. martia } \\
\text { 5P. multidentata } \\
\text { 6D. quadrimaculatus } \\
\text { 7L. elegans } \\
\text { 8P. sivado } \\
\text { 9L. friesii } \\
\text { 10 P. spinosus }\end{array}$ & $\begin{array}{c}-\left.2\right|_{10} ^{6}{ }^{7} 8 \\
-4\end{array}$ & 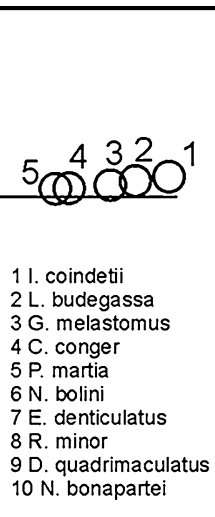 \\
\hline 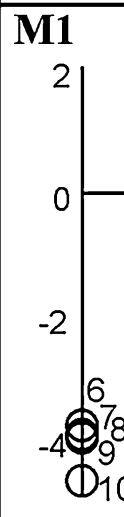 & $\begin{array}{l}\text { 1I. coindetii } \\
2 \text { E. spinax } \\
3 \mathrm{G} \text {. leioglossus } \\
4 \mathrm{H} \text {. mediterraneus } \\
5 \mathrm{~A} \text {. foliacea } \\
6 \mathrm{~L} \text {. friesii } \\
7 \text { E. denticulatus } \\
8 \mathrm{~A} \text {. lacazei } \\
9 \mathrm{~T} \text { lucerna } \\
10 \mathrm{R} \text {. minor }\end{array}$ & \begin{tabular}{l|l}
-2 & \\
$\$_{\$ 10}^{8}$ \\
$-4 \$_{10}$
\end{tabular} & $\begin{array}{l}\text { 11. coindetii } \\
2 \mathrm{G} \text {. melastomus } \\
3 \mathrm{~L} \text {. budegassa } \\
4 \mathrm{P} \text {. heterocarpus } \\
\text { 5 G. leioglossus } \\
6 \text { L. friesii } \\
\text { 7 A. laterna } \\
\text { 8A. megalokynodon } \\
\text { 9A. sphyraena } \\
\text { 10 R. minor }\end{array}$ & $\begin{array}{l}-2 \underbrace{6}_{8} \\
8 \\
8 \\
10\end{array}$ & $\begin{array}{l}4320^{1} \\
\text { 1 P. martia } \\
\text { 2 P. sivado } \\
3 \text { P. longirostris } \\
4 \mathrm{G} \text {. melastomus } \\
\text { 51. coindetii } \\
6 \mathrm{~L} \text {. friesii } \\
7 \mathrm{M} \text {. lanata } \\
\text { 8 T. lyra } \\
\text { 9A. megalokynodon } \\
\text { 10 S. nigrescens }\end{array}$ \\
\hline $\begin{array}{l}0 \\
-2 \\
6 \\
6 \\
10\end{array}$ & $\begin{array}{l}4321 \\
\text { 1 G. melastomus } \\
\text { 2I. coindeti } \\
\text { 3L. budegassa } \\
4 \mathrm{M} \text {. surmuletus } \\
\text { 5 P. heterocarpus } \\
\text { 6L. friesii } \\
\text { 7R. minor } \\
8 \mathrm{~L} \text {. elegans } \\
\text { 9 Myctophidae } \\
\text { 10 I. communissimus }\end{array}$ & $-2 \$_{10}^{6} 78$ & $\begin{array}{l}5.321 \\
5000 \\
\text { 1 I. coindetii } \\
\text { 2 G. melastomus } \\
3 \mathrm{~L} \text {. budegassa } \\
4 \mathrm{G} \text {. leioglossus } \\
5 \mathrm{M} \text {. punctatum } \\
6 \mathrm{R} \text {. minor } \\
7 \mathrm{C} \text {. maderensis } \\
8 \mathrm{~N} \text {. melanurum } \\
9 \mathrm{H} \text {. benoiti } \\
10 \mathrm{~S} \text {. veranyi }\end{array}$ & 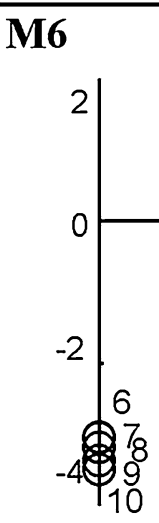 & $\begin{array}{l}1 \mathrm{P} \text {. martia } \\
2 \mathrm{M} \text {. rutllanti } \\
3 \mathrm{I} \text {. coindetii } \\
4 \mathrm{G} \text {. melastomus } \\
5 \mathrm{~L} \text {. budegassa } \\
6 \mathrm{C} \text {. sloani } \\
7 \mathrm{E} \text {. denticulatus } \\
8 \mathrm{~S} \text {. phaeton } \\
9 \mathrm{~L} \text {. dofleini } \\
10 \mathrm{~L} \text {. friesii }\end{array}$ \\
\hline
\end{tabular}

shark on the upper and middle slope of the Ionian Sea (Sion et al. 2004) and is considered a generalist feeder living and foraging close to sandy bottom. The black anglerfish which is generally abundant in the North-western Ionian Sea (Carlucci et al. 2009) is a large-bodied bottom species that lives between 70 and $800 \mathrm{~m}$ of depth being a specialized ichthyophagous predator with ambush behavior that attracts potential prey with the modified first ray of the dorsal fin that acts as a lure (Preciado et al. 2006). C. conger is considered a large opportunistic predator living and foraging close to rocky areas where it finds refuge during the day (Morato et al. 1999; Xavier et al. 2010). Recently, it was found to be relatively abundant in the SML CWC province (D'Onghia et al. 2012).

In addition, the high abundance observed for high TL fishes in the SML CWC province could be due to the lower fishing pressure observed in this area (D'Onghia et al. 2010).

This could also be interpreted as a consequence of the absence of a fishing down the web effect. Fishing down is a succession which reverses the usual evolutionary sequence (Pauly et al. 1998). It consists of a gradual loss of larger organisms, species and structural diversity, and a gradual 
replacement of recently evolved, derived groups (e.g., bony fishes) by more primitive opportunistic groups (e.g., invertebrates). This is a common effect reckoned in exploited areas that seem to be absent in the SML CWC province due to the lower fishing pressure making this area a peculiar in the Mediterranean context.

\section{Conclusions}

The ecological model of the demersal assemblages around and inside the SML CWC province represents a first attempt to integrate the available biological data from the area into a holistic and comprehensive system-view approach. The mass-balance modeling of the benthopelagic food web provides a summary of current knowledge of the biomass, consumption, production and trophic structure in a peculiar Mediterranean ecosystem. This is in fact a rare example of living Madrepora-Lophelia-bearing coral mounds characterized by a high biodiversity in the context of the muddy bathyal grounds in the Mediterranean Sea where corals play as a de facto exclusion system from intense fishery exploitation. This study constitutes the first attempt at modeling the deep demersal fauna at the species level and one of the few studies (besides Tecchio et al. 2013) on deep Mediterranean environment trophic web. Results highlight important features in terms of the structure and functioning of the system, such as the high level of activity maintained by intermediate TLs and the important role of top-down control acting in the community.

In the SML CWC province, it is detected a high abundance of high TL organisms probably due to the low fishing activity in this area. This is the main consequence of the absence of a fishing down the web effect that makes this area a peculiar environment in the widely exploited Mediterranean context.

The system simulation is a valuable tool for understanding ecosystem functioning and for developing systemscale management scenarios. In fact, it is possibly investigating the consequences of certain actions, such as fishing pressure increase or legal protection of specific areas.

Acknowledgements This study benefited from data recorded during the GRUND funded by Italian Government, MEDITS financed by Italian Government and EU DG MARE. Elaborations were carried out as part of Italian PRIN OBAMA project (Ministry of University and Research-MIUR)

\section{References}

Allen R (1971) Relation between production and biomass. J Fish Res Board Can 28:1573-158
Allesina S, Bondavalli C (2003) Steady state of ecosystem flow networks: a comparison between balancing procedures. Ecol Model 165(2-3):221-229

Bănaru D, Mellon-Duval C, Roos D, Bigot JL, Souplet A, Jadaud A, Beaubrun P, Fromentin JM (2013) Trophic structure in the Gulf of Lions marine ecosystem (north-western Mediterranean Sea) and fishing impacts. J Mar Syst 111-112:45-68

Barausse A, Duci A, Mazzoldi C, Artioli Y, Palmeri L (2009) Trophic network model of the Northern Adriatic Sea: analysis of an exploited and eutrophic ecosystem. Estuar Coast Shelf Sci 83:577-590

Bearzi G, Holcer D, Notarbartolo Di Sciara G (2004) The role of historical dolphin takes and habitat degradation in shaping the present status of northern Adriatic cetaceans. Aquat Conserv Mar Freshw Ecosyst 14:363-379

Bertrand JA, Gil de Sola L, Papaconstantinou C, Relini G, Souplet A (2000) An international bottom trawl survey in the Mediterranean: the MEDITS programme. IFREMER Actes Colloq 26:76-93

Bertrand JA, Leonori I, Dremière PY, Cosimi G (2002) Depth trajectory and performance of a trawl used for an international bottom trawl survey in the Mediterranean. Sci Mar 66:169-182

Bianchi CN, Morri C (2000) Marine biodiversity of the Mediterranean Sea: situation, problems and prospects for future research. Mar Pollut Bull 40:367-376

Budillon G, Lo Bue N, Siena G, Spezie G (2010) Hydrographic characteristics of water masses and circulation in the Northern Ionian Sea. Deep Sea Res II 57(5-6):441-457

Capezzuto F, Carlucci R, Maiorano P, Sion L, Battista D et al (2010) The bathyal benthopelagic fauna in the northwestern Ionian Sea: structure, patterns and interactions. Chem Ecol 26:199-217

Capezzuto F, Maiorano P, Panza M, Indennidate A, Sion L et al (2012) Occurrence and behaviour of Paromola cuvieri (Crustacea, Decapoda) in the Santa Maria di Leuca cold-water coral community (Mediterranean Sea). Deep Sea Res I 59:1-7

Carlier A, Le Guilloux E, Olu K, Sarrazin J, Mastrototaro F et al (2009) Trophic relationships in a deep Mediterranean cold-water coral bank (Santa Maria di Leuca, Ionian Sea). Mar Ecol Prog Ser 397:125-137

Carlucci R, Capezzuto F, Maiorano P, Sion L, D’Onghia G (2009) Distribution, population structure and dynamics of the black anglerfish (Lophius budegassa) (Spinola, 1987) in the Eastern Mediterranean Sea. Fish Res 95(1):76-87

Christensen V (2003) A model of trophic interactions in the North Sea in 1981, the year of the stomach. Dana 11(1):1-19

Christensen V, Walters C (2004) Ecopath with Ecosim: methods, capabilities and limitations. Ecol Model 172(2-4):109-139

Christensen V, Walters CJ, Pauly D (2005) Ecopath with Ecosim: a user's guide. Fisheries Centre, University of British Columbia, Vancouver

Coll M, Palomera I, Tudela S, Sardà F (2006) Trophic flows, ecosystem structure and fishing impacts in the South Catalan Sea, North-western Mediterranean. J Mar Syst 59:63-96

Coll M, Santojanni A, Palomera I, Tudela S, Arneri E (2007) An ecological model of the Northern and Central Adriatic Sea: analysis of ecosystem structure and fishing impacts. J Mar Syst 67:119-154

Corselli C (2010) The APLABES programme: physical, chemical and biological characterization of deep-water coral ecosystems from the Ionian Sea (Mediterranean). Deep Sea Res II 57:323-492

D’Onghia G, Tursi A, Maiorano P, Matarrese A, Panza M (1998) Demersal fish assemblages from the bathyal grounds of the north-western Ionian Sea. Ital J Zool 65:287-292

D’Onghia G, Mastrototaro F, Matarrese A, Politou CY, Mytilineou CH (2003) Biodiversity of the upper slope demersal community in the eastern Mediterranean: preliminary comparison between 
two areas with and without trawl fishing. J Northwest Atl Fish Sci 31:263-273

D’Onghia G, Maiorano P, Sion L, Giove A, Capezzuto F et al (2010) Effects of deep-water coral banks on the abundance and size structure of the megafauna in the Mediterranean Sea. Deep Sea Res Part II 57:397-411

D’Onghia G, Indennidate A, Giove A, Savini A, Capezzuto F et al (2011) Distribution and behaviour of the deep-sea benthopelagic fauna observed using towed cameras in the Santa Maria di Leuca cold water coral province. Mar Ecol Prog Ser 443:95-110

D’Onghia G, Maiorano P, Carlucci R, Capezzuto F, Carluccio A et al (2012) Comparing deep-sea fish fauna between coral and noncoral "megahabitats" in the Santa Maria di Leuca cold-water coral province (Mediterranean Sea). PLoS ONE 7(9):e44509. doi:10.1371/journal.pone.0044509

D’Onghia G, Calculli C, Capezzuto F, Carlucci R, Carluccio A et al (2016) Anthropogenic impact in the Santa Maria di Leuca coldwater coral province (Mediterranean Sea): observations and conservation straits. Deep Sea Res Part II Top Stud Oceanogr. doi:10.1016/j.dsr2.2016.02.012

Finn JT (1976) Measures of ecosystem structure and function derived from analysis of flows. J Theor Biol 56:363-380

Fouzai N, Coll M, Palomera I, Santojanni A, Arneri E et al (2012) Fishing management scenarios to rebuild exploited resources and ecosystems of the Northern-Central Adriatic (Mediterranean Sea). J Mar Syst 102-104:39-51

Freiwald A, Beuck L, Rüggeberg A, Taviani M, Hebbeln D, Participants RVMCM (2009) The white coral community in the Central Mediterranean Sea revealed by ROV surveys. Oceanography 22:58-74

Indennidate A, Carlucci R, Maiorano P, Sion L, D’Onghia G (2010) Fishing effort and catch composition on the boundaries of Santa Maria di Leuca deep-water coral bank. Biol Mar Mediterr 17(1):340-341

Jackson JBC, Kirby MX, Berger WH, Bjorndal KA, Botsford LW et al (2001) Historical overfishing and the recent collapse of coastal ecosystems. Science 293:629-638

Leontief WW (1951) The structure of american economy, 1919-1939, 2nd edn. Oxford University Press, New York

Libralato S, Pranovi F, Raicevich S, Giovanardi O (2004) Mixed trophic impact and transfer efficiency as indicators of species' role and ecosystem state. Biol Mar Mediterr 11(2):255-264

Libralato S, Christensen V, Pauly D (2006) A method for identifying keystone species in food web models. Ecol Model 195(3-4):153-171

Maiorano P, Sion L, Carlucci R, Capezzuto F, Giove A et al (2010) The demersal faunal assemblage of the North-Western Ionian Sea (Central Mediterranean): current knowledge and perspectives. Chem Ecol 26:219-240

Margaleff R (1968) Perspectives in ecological theory. University of Chicago press, Chicago

Mastrototaro F, D'Onghia G, Corriero G, Matarrese A, Maiorano P et al (2010) Biodiversity of the white coral bank off Cape Santa Maria di Leuca (Mediterranean Sea): an update. Deep Sea Res II 57:412-430

Matarrese A, D’Onghia G, Tursi A, Basanisi M (1996) New information on the ichthyofauna of the south-eastern Italian coast (Ionian Sea). Cybium 20:197-211

Morales-Zárate MV, Lluch-Cota SE, Serviere-Zaragoza E, Guzmán del Próo S (2011) Modeling an exploited rocky coastal ecosystem: Bahia Tortugas, Mexico. Ecol Model 222: 1185-1191

Morato T, Solà E, Grós MP, Menezes G (1999) Diets of forkbeard (Phycis phycis) and conger eel (Conger conger) off the Azores during spring of 1996 and 1997. Arquipél (Life Mar Sci) 17:51-64
Neira S, Arancibia H, Cubillos L (2004) Comparative analysis of trophic structure of commercial fishery species off Central Chile in 1992 and 1998. Ecol Model 172:233-248

Odum EP (1969) The strategy of ecosystem development. Science 164:262-270

Odum WE, Heald EJ (1975) The detritus-based food web of an estuarine mangrove community. In: Cronin LE (ed) Estuarine research. Academic Press Inc, New York, pp 265-286

Paoli C, Morten A, Bianchi CN, Morri C, Fabiano M, Vassallo P (2016) Capturing ecological complexity: OCI, a novel combination of ecological indices as applied to benthic marine habitats. Ecol Ind 66:86-102

Pauly D, Christensen V (1995) Primary production required to sustain global fisheries. Nature 374:255-257

Pauly D, Christensen V, Dalsgaard J, Froese R, Torres F (1998) Fishing down marine food webs. Science 279:860-863

Power ME, Tilman D, Estes JA, Menge BA, Bond WJ et al (1996) Challenges in the quest for keystones. Bioscience 46:609-620

Pranovi F, Libralato S, Raicevich S, Granzotto A, Pastres R et al (2003) Mechanical clam dredging in Venice lagoon: ecosystem effects evaluated with trophic mass-balance model. Mar Biol 143:393-403

Preciado I, Velasco F, Olaso I, Landa J (2006) Feeding ecology of black anglerfish Lophius budegassa: seasonal, bathymetric and ontogenetic shifts. J Mar Biol Assoc U K 86:877-884

Relini G, Biagi F, Serena F, Belluscio A, Spedicato MT et al (2000) I Selaci pescati con lo strascico nei mari italiani. Biol Mar Mediterr 7:347-384

Sánchez F, Olaso I (2004) Effects of fisheries on the Cantabrian Sea shelf ecosystem. Ecol Model 172(2-4):151-174

Savini A, Corselli C (2010) High-resolution bathymetry and acoustic geophysical data from Santa Maria di Leuca Cold Water Coral province (Northern Ionian Sea-Apulian continental slope). Deep Sea Res II 57(5-6):326-344

Savini A, Vertino A, Marchese F, Beuck L, Freiwald A (2014) Mapping Cold-Water Coral Habitats at Different Scales within the northern Ionian Sea (central Mediterranean): an assessment of coral coverage and associated vulnerability. PLoS ONE 9(1):e87108

Sion L, Bozzano A, D’Onghia G, Capezzuto F, Panza M (2004) Chondrichthyes species in deep waters of the Mediterranean Sea. Sci Mar 68(3):153-162

Stergiou KI, Karpouzi VS (2002) Feeding habits and trophic levels of Mediterranean fish. Rev Fish Biol Fish 11:217-254

Taviani M, Remia A, Corselli C, Freiwald A, Malinverno E et al (2005) First geo-marine survey of living cold-water Lophelia reefs in the Ionian Sea (Mediterranean basin). Facies 50:409-417

Tecchio S, Coll M, Christensen V, Company JB, Ramírez-Llodra E et al (2013) Food web structure and vulnerability of a deep-sea ecosystem in the NW Mediterranean Sea. Deep Sea Res Part I $75: 1-15$

Tsagarakis K, Coll M, Giannoulaki M, Somarakis S, Papaconstantinou C et al (2010) Food-web traits of the North Aegean Sea ecosystem (Eastern Mediterranean) and comparison with other Mediterranean ecosystems. Estuar Coast Shelf Sci 88:233-248

Tursi A, Mastrototaro F, Matarrese A, Maiorano P, D'Onghia G (2004) Biodiversity of the white coral reefs in the Ionian Sea (Central Mediterranean). Chem Ecol 20:107-116

Ulanowicz RE, Puccia CJ (1990) Mixed trophic impacts in ecosystems. Coenoses 5:7-16

Ulanowicz RE, Scharler UM (2008) Least inference methods for constructing networks of trophic flows. Ecol Model 210:278-286

Vassallo P, Fabiano M, Vezzulli L, Sandulli R, Marques JC et al (2006) Assessing the health of coastal marine ecosystems: a holistic approach based on sediment micro and meio-benthic measures. Ecol Ind 6:525-542 
Vassallo P, Paoli C, Schiavon G, Albertelli G, Fabiano M (2013) How ecosystems adapt to face disruptive impact? The case of a commercial harbor benthic community. Ecol Ind 24:431-438

Viettia RC, Albertellia G, Alianib S, Bava S, Bavestrello G et al (2010) The Ligurian Sea: present status, problems and perspectives. Chem Ecol 26:319-340
Xavier JC, Cherel Y, Assis CA, Sendão J, Borges TC (2010) Feeding ecology of conger eels (Conger conger) in north-east Atlantic waters. J Mar Biol Assoc U K 90:493-501

Zuozhi C, Yongsong Q, Shannan X (2011) Changes in trophic flows and ecosystem properties of the Beibu Gulf ecosystem before and after the collapse of fish stocks. Ocean Coast Manag 54:601-611 